\title{
41. OXYGEN AND STRONTIUM ISOTOPIC COMPOSITIONS AND THORIUM AND URANIUM CONTENTS OF BASALTS FROM DSDP 37 CORES
}

\author{
J. Gray and G.L. Cumming, Department of Physics, University of Alberta, Edmonton, Canada \\ and \\ R. St J. Lambert, Department of Geology, University of Alberta, Edmonton, Canada
}

\section{INTRODUCTION}

The analyses reported are from 26 samples supplied as uncrushed core, weighing between 17 and $70 \mathrm{~g}$. These samples were sectioned and dried in an oven for $24 \mathrm{hr}$ at $60^{\circ} \mathrm{C}$, crushed in a steel mortar and pestle, and ground to a fine powder either in a tungsten carbide swing-mill (larger samples) or by hand in an agate mortar (small samples). Aliquots of these powders were used for $\mathrm{Sr}$ and $\mathrm{Pb}$ isotopic analysis by Yamaguchi et al. at the University of British Columbia (this volume) and for whole-rock XRF analysis by Lambert and Holland (this volume). Further analyses will be reported elsewhere and the data from the three groups will be integrated.

\section{STRONTIUM ISOTOPES}

Thirteen analyses for $\mathrm{Rb}, \mathrm{Sr}$, and $\mathrm{Sr}^{87} / \mathrm{Sr}^{86}$ are available (Table 1, Figures 1 and 2), the range of figures being almost identical to those of Yamaguchi et al. (this volume) including having the lowest $\mathrm{Sr}^{87} / \mathrm{Sr}^{86}$ at the bottom of each hole. The range of figures from 0.70315 \pm 7 to $0.70450 \pm 7$ is on the high side for a set of rocks from one oceanic area, and the values themselves are generally higher than those from Icelandic and Atlantic ocean-floor basalts (Hart et al., 1973; O'Nions and Pankhurst, 1974), but are similar to those from Leg 17 (Bass et al., 1973). Analytical error seems to be most unlikely as a cause of these differences.

The range of the figures appears to be related to exchange with seawater strontium (and perhaps rubidium) as illustrated in Figures 1 and 2. In Figure 2 we note the presence of calcite and state $\mathrm{CO}_{2}$ figures from the nearest portions of core, where available. There is a broad but by no means perfect correlation between the visible presence of carbonate, association with $\mathrm{CO}_{2}$-rich portions of core, and high $\mathrm{Sr}^{87} / \mathrm{Sr}^{86}$ and $\delta \mathrm{O}^{18}$. We conclude that the apparent 100-150 m.y. "isochron" of Figure 1 is spurious. However, if so, it is curious that the samples with higher $\mathrm{Sr}^{87} / \mathrm{Sr}^{86}$ in the low $\mathrm{Sr}^{87} / \mathrm{Sr}^{86}$ series (e.g., 332A $21-1$ and 332B $21-1$ ) have correspondingly higher $\mathrm{Rb} / \mathrm{Sr}$. The "isochron" implies uptake of $\mathrm{Rb}$ or loss of $\mathrm{Sr}$ in proportion to gain of $\mathrm{Sr}^{87}$ from seawater. Loss of $\mathrm{Sr}$ seems most unlikely, but detailed discussion must await analysis of individual minerals.

If it is assumed that unaltered basalt has $\delta \mathrm{O}^{18}=6.0$, then extrapolation along the crude linear trend seen in Figure 2 gives an intercept of $\mathrm{Sr}^{87} / \mathrm{Sr}^{86}$ of 0.7030 for the composition of the primary $\mathrm{Sr}$ in these rocks. O'Nions and Pankhurst (1974) gave $0.70314 \pm 4$ for ridge samples at $63^{\circ} \mathrm{N}$ and $0.70294 \pm 4$ from $58^{\circ} \mathrm{N}$ to $52^{\circ} \mathrm{N}$.

\section{OXYGEN ISOTOPES}

The data for 24 samples are given in Table 2 and Figure 2. The two figures for each of 334-24-3 and 3358-3 are from separate powders from two fragments of core, broken from one piece during sample preparation. Apart from the low values from the serpentinized plagioclase peridotite $334-24-3$, the remainder range from $\delta \mathrm{O}^{18}=6.5$ to 9.9 . There is a crude correlation between, high $\delta \mathrm{O}^{18}$ and the presence of carbonate, but our data are too incomplete to permit a quantitative evaluation. If solely due to carbonate precipitated from seawater in veins and vesicles, rocks such as 332B-35-2 should contain $\sim 10 \%$ calcite with $\delta \mathrm{O}^{18}=+40$. However, this basalt contains only $\sim 1 \%$ calcite in thin section and larger-scale exchange with silicates is implied. Enough exceptions also exist in this set of specimens to the suggested correlation of secondary carbonate with high $\delta \mathrm{O}^{18}$ (e.g., the samples from $332 \mathrm{~A}$ $12-1$ with $\delta \mathrm{O}^{18}=8.2$ and 8.8 have no carbonate in thin section) for it to be essential that some other minerals be involved in this $\mathrm{O}^{18}$ enrichment.

The mean $\delta \mathrm{O}^{18}$ for $332 \mathrm{~A}$ is 7.3 , for $332 \mathrm{~B}$ it is 7.8 , and for 335 it is 9.0. These figures correspond to altered basalts with 1 to 3 weight percent $\mathrm{H}_{2} \mathrm{O}$ (Muehlenbachs and Clayton, 1972, fig. 1): data on $\mathrm{H}_{2} \mathrm{O}$ so far available (26 March 1974 listing) show similarly high levels of $\mathrm{H}_{2} \mathrm{O}$ in Leg 37 basalts. Thus it is provisionally concluded that these basalts have suffered $\mathrm{O}^{18}$ enrichment, probably via formation of "clays" rather than via carbonates (Muehlenbachs and Clayton, 1972), to the extent of up to $15 \%$ "clay" in the case of the samples with highest $\delta \mathrm{O}^{18}$. Such a high degree of alteration will presumably be sufficient to make assessment and use of minor and trace element geochemistry (particularly the alkalies) rather uncertain.

\section{THORIUM AND URANIUM}

Th and $U$ analyses by the delayed-neutron method are given in Table 3, and $U$ is compared with $\mathrm{Zr}$ and $\mathrm{K}$ in Figures 3 and 4. With the exception of 332B-14-1, which has anomalously low $\mathrm{U}$ by comparison with similar rocks from 332B (Figures 3 and 4), the $U$ data fall neatly into groups following the geochemical classification of Lambert and Holland (this volume). However, $\mathrm{K} / \mathrm{U}$ ratios vary widely, averaging 33,000 in $334,22,500$ in the "low $\mathrm{Zr}$, high Mg" subset of $332 \mathrm{~A}$ and $\mathrm{B}$, and 11,000 in the "high $\mathrm{Zr}$, low Mg" subset, excluding the one anomalous Sample 332B-14-1 (K data from Lambert and Holland). These high ratios immediately raise the question of $U$ loss, particularly in 335 and the low-Zr subset. At Site 335, the possibility of 
TABLE 1

Strontium Isotope Data from Leg 37

\begin{tabular}{|c|c|c|c|c|}
\hline $\begin{array}{c}\text { Sample } \\
\text { (Interval in } \mathrm{cm} \text { ) }\end{array}$ & $\mathrm{Rb}^{\mathrm{a}}$ & $\mathrm{Sr}^{\mathrm{a}}$ & $\mathrm{Rb}^{87} / \mathrm{Sr}^{86}$ & $\mathrm{Sr}^{87} / \mathrm{Sr}^{86}$ \\
\hline $\begin{array}{l}332 \mathrm{~A}-8-1, \\
98-100(\# 11)\end{array}$ & $6.77 \pm 0.37^{b}$ & $118.3 \pm 0.7$ & $0.165 \pm 0.009$ & $0.70328 \pm 7^{c}$ \\
\hline $\begin{array}{l}98-100(\# 11) \\
332 A-12-1, \\
123(\# 12 D)\end{array}$ & $5^{\mathrm{d}}$ & $120^{\mathrm{d}}$ & 0.12 & $0.70351 \pm 7$ \\
\hline $\begin{array}{l}332 \mathrm{~A}-21-1, \\
57-59(\# 4)\end{array}$ & $4.31 \pm 0.20$ & $108.2 \pm 0.4$ & $0.115 \pm 0.005$ & $0.70338 \pm 7$ \\
\hline $\begin{array}{l}332 \mathrm{~A}-28-1, \\
34-36(\# 4)\end{array}$ & $5.19 \pm 0.24$ & $116.2 \pm 0.5$ & $0.129 \pm 0.006$ & $0.70328 \pm 7$ \\
\hline $\begin{array}{l}332 \mathrm{~A}-29-1, \\
37-39(\# 5)\end{array}$ & $6.60 \pm 0.20$ & $111.6 \pm 1.0$ & $0.171 \pm 0.005$ & $0.70329 \pm 7$ \\
\hline $\begin{array}{l}332 \mathrm{~A}-40-3, \\
37-39(\# 4 \mathrm{~B})\end{array}$ & $2.08 \pm 0.20$ & $94.8 \pm 0.5$ & $0.063 \pm 0.006$ & $0.70318 \pm 7$ \\
\hline $\begin{array}{l}\text { 332B-6-1, } \\
\sim 100(\# 11 \mathrm{~A})\end{array}$ & $8.10 \pm 0.20$ & $114.5 \pm 0.4$ & $0.204 \pm 0.005$ & $0.70363 \pm 7$ \\
\hline $\begin{array}{l}332 \mathrm{~B}-13-1, \\
70-72(\# 6)\end{array}$ & $3.42 \pm 0.25$ & $123.7 \pm 1.0$ & $0.080 \pm 0.006$ & $0.70410 \pm 7$ \\
\hline $\begin{array}{l}332 \mathrm{~B}-21-1, \\
27-30 \text { (\#1B) }\end{array}$ & $3.01 \pm 0.20$ & $62.1 \pm 0.1$ & $0.140 \pm 0.009$ & $0.70338 \pm 7$ \\
\hline $\begin{array}{l}\text { 332B-35-2, } \\
105-108(\# 1 N)\end{array}$ & $3.42 \pm 0.46$ & $85.8 \pm 0.6$ & $0.115 \pm 0.016$ & $0.70450 \pm 7$ \\
\hline $\begin{array}{l}332 \mathrm{~B}-47-2, \\
67-70 \text { (\#P5) }\end{array}$ & $0.87 \pm 0.27$ & $108.7 \pm 0.3$ & $0.023 \pm 0.007$ & $0.70315 \pm 7$ \\
\hline $\begin{array}{l}335-7-2, \\
95-97 ?(\# 7 B)\end{array}$ & $6.95 \pm 0.20$ & $102.7 \pm 0.5$ & $0.195 \pm 0.005$ & $0.70449 \pm 7$ \\
\hline $\begin{array}{l}335-10-6, \\
28-30(\# 2)\end{array}$ & $3.38 \pm 0.20$ & $95.3 \pm 0.3$ & $0.102 \pm 0.006$ & $0.70407 \pm 7$ \\
\hline
\end{tabular}

${ }^{\mathrm{a}} \mathrm{Rb}$ and $\mathrm{Sr}$ determined by X-ray analysis; 4 replicates. Corrected for interferences from $\mathrm{U}, \mathrm{Th}, \mathrm{Pb}, \mathrm{Rb}$, and $\mathrm{Sr}$.

${ }^{b}$ Errors are S.D. of replicate analyses, increased to 0.20 where smaller values were obtained. Errors indicate position.

${ }^{c}$ Error quoted is mean of internal errors, and the same as A.N.U. laboratory error estimate.

${ }^{\mathrm{d}}$ From Lambert and Holland (this volume).

${ }^{\text {e }} \mathrm{Sr}$ ratios must be decreased by 0.00021 on the basis of replicate analysis on NBS SRM 987 which yielded $0.71035 \pm 0.0002$ when measured on the instrument used for these analyses, W. Compston (personal communication).

a threefold depletion must be regarded as real in view of $\delta \mathrm{O}^{18}=9$ as discussed above. In the "low- $\mathrm{Zr}$ " rocks, however, the situation is much less clear, because these have low $\mathrm{Fe}_{2} \mathrm{O}_{3} / \mathrm{MgO}$ (but show no petrographic evidence for loss of $\mathrm{Fe}_{2} \mathrm{O}_{3}$ or gain of $\mathrm{MgO}$ ) and are consistently and uniformly low in $\mathrm{Ti}, \mathrm{Y}, \mathrm{Zr}$, and $\mathrm{Nb}$ elements usually regarded as inert in alteration processes (Cann, 1970; Pearce and Cann, 1973). Also, the "low-Zr" basalt 332A-40-3, 37-39 cm (\#4B) has comparatively low $\mathrm{Sr}^{87} / \mathrm{Sr}^{86}$ (Figure 1) accompanying its $\mathrm{K} / \mathrm{U}$ of 24,000 , suggesting lack of exchange, although it has $\delta \mathrm{O}^{18}=7.4$.

The mean $U$ figure, $0.180 \mathrm{ppm}$, is rather higher than the mean of 0.08 for three samples from Leg 17 (Bass et al., 1973) and 0.15 for six samples from Leg 15 (Donnelly et al., 1973; excepting two K-rich samples). These other sets had mean K/U of 48,000 and 10,000 , respectively. Th is unfortunately comparatively poorly determined by the delayed neutron method when in low concentrations, but the arithmetic mean is $0.48 \mathrm{ppm}$ (if the below detection limit figures average $0.15 \mathrm{ppm}$ ) and mean $\mathrm{Th} / \mathrm{U}=2.7$. For those samples with $\mathrm{Th}$ above the detection limit, excluding the anomalous sample 332B-14-1, 33-35 cm (\#1), Th/U = 3.0.

\section{CONCLUSIONS}

The strontium isotope measurements combined with oxygen isotope data indicate contamination and/or reaction by seawater, probably via the formation of clay minerals and perhaps also by addition of secondary carbonate. An "initial" $\mathrm{Sr}^{87} / \mathrm{Sr}^{86}$ of 0.7030 is suggested for these samples, with the actual present-day range being 0.70315 to 0.70450 , and the arithmetic mean 0.70363 . The mean $\delta \mathrm{O}^{18}$ for basalts is +7.75 . Uranium and thorium data show below-average contents with average $U=0.180 \mathrm{ppm}, \mathrm{K} / \mathrm{U}=20,000$, and $\mathrm{Th} / \mathrm{U}=3.0$, although the latter figure is not accurately defined. Some recent $U$ loss may have occurred, but other geochemical parameters suggest that the quantity lost has not been large.

\section{ACKNOWLEDGMENTS}

$\mathrm{U}$ and Th were determined by J.G. using the delayedneutron technique at McMaster University, Hamilton, Ontario. $\mathrm{Sr}$ isotopes and $\mathrm{Rb}$ and $\mathrm{Sr}$ concentrations were measured by G.L.C. using mass spectrometry and XRF in the laboratories of Dr. W. Compston at the Australian National University at Canberra. $\mathrm{O}$ isotopes were measured in the laboratory of Dr. S. Epstein at California Institute of 


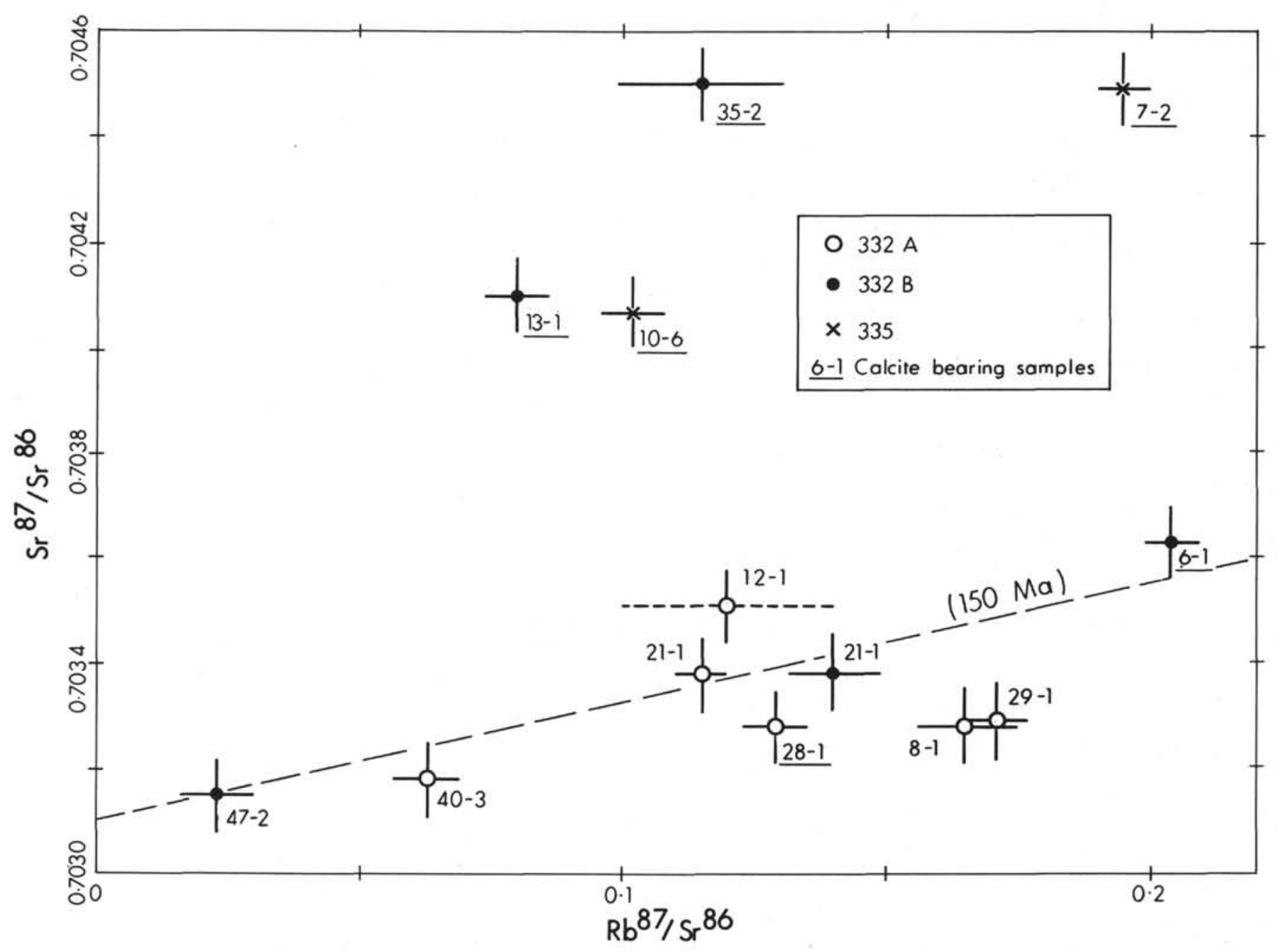

Figure 1. $\mathrm{Sr}^{87} / \mathrm{Sr}^{86}$ and $\mathrm{Rb}^{87} / \mathrm{Sr}^{86}$ in basalts from Leg 37. The apparent isochron is meaningless, because of secondary isotopic exchange.

Technology. We are particularly grateful to Drs. Epstein and Compston for their assistance in this project.

\section{REFERENCES}

Bass, M.N., Moberly, R., Rhodes, J.M., Shih, C., and Church, S.E., 1973. Volcanic rocks cored in the central Pacific, Leg 17, DSDP: Am. Geophys. Union Trans., v. 54 , p. $991-995$.

Cann, J.R., 1970. Rb, Sr, Y, Zr, and $\mathrm{Nb}$ in some ocean floor basaltic rocks: Earth Planet. Sci. Lett., v. 10, p. 7-11.

Donnelly, T.W., Kay, R., and Rogers, J.J.W., 1973. Chemical petrology of Caribbean basalts and dolerites; Leg 15, DSDP: Am. Geophys. Union Trans., v. 54, p. 1002-1004.
Hart, S.R., Schilling, J-G., and Powell, J.L., 1973. Basalts from Iceland and along the Reykjanes Ridge: $\mathrm{Sr}$ isotope geochemistry: Nature Phys. Sci., v. 246, p. 104-107.

Muehlenbachs, K. and Clayton, R.N., 1972. Oxygen isotope studies of fresh and weathered submarine basalts: Canadian J. Earth Sci., v. 9, p. 172-184.

O'Nions, R.K. and Pankhurst, R.J., 1974. Petrogenetic significance of isotope and trace element variations in volcanic rocks from the Mid-Atlantic: J. Petrol., v. 15, p. 603-634.

Pearce, J.A. and Cann, J.R., 1973. Tectonic setting of basic volcanic rocks determined using trace element analyses: Earth Planet. Sci. Lett., v. 19, p. 290-300. 


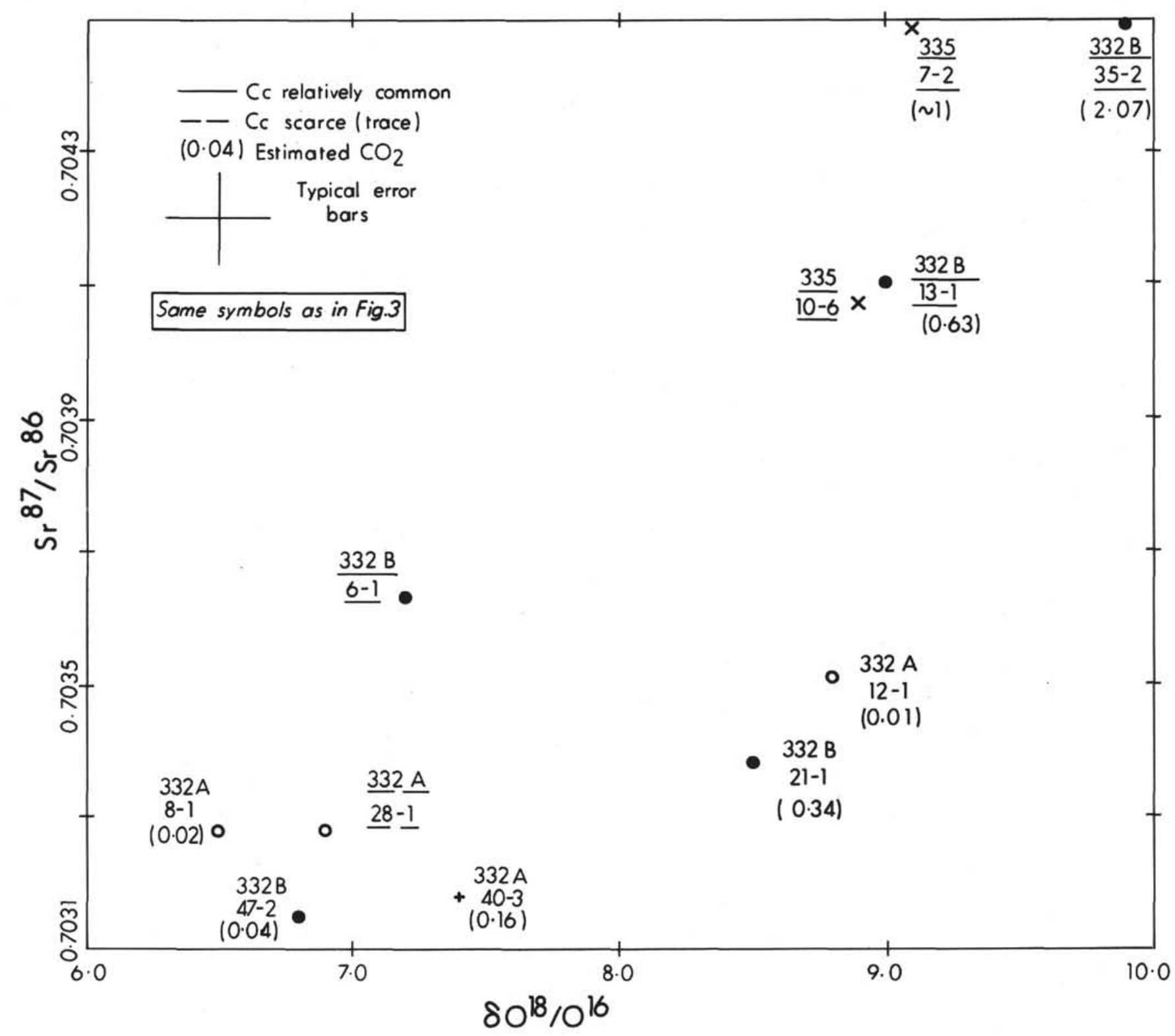

Figure 2. $\mathrm{Sr}^{87} / \mathrm{Sr}^{86}$ and $\delta \mathrm{O}^{18} / \mathrm{O}^{16}$ in basalts from Leg 37. Note the general positive correlation. 
TABLE 2

Oxygen Isotope Data from Leg 37

\begin{tabular}{|c|c|}
\hline $\begin{array}{c}\text { Sample } \\
\text { (Interval in } \mathrm{cm} \text { ) }\end{array}$ & $\delta \mathrm{O}^{18} / \mathrm{O}^{16}$ sMow \\
\hline
\end{tabular}

Hole 332A

$\begin{array}{ll}7-2,15-17(\# 9) & +7.2^{\mathrm{a}} \\ 8-1,98-100(\# 11) & +6.5 \\ 12-1,93-97(\# 11 \mathrm{~A}) & +8.2 \\ 12-1,123(\# 12 \mathrm{D}) & +8.8 \\ 14-1,127-129(\# 12) & +6.8 \\ 26-1,43-45(\# 2) & +7.3 \\ 28-1,34-36(\# 4) & +6.9^{\mathrm{a}} \\ 28-2,57-59(\# 9) & +7.0^{\mathrm{a}} \\ 32-1,106-108(\# 14 \mathrm{~B}) & +6.9 \\ 40-3,37-39(\# 4 \mathrm{~B}) & +7.4^{\mathrm{b}}\end{array}$

Hole 332B

$\begin{array}{ll}2-5,103-106(\# 10) & +7.7^{\mathrm{b}} \\ 6-1, \sim 100(\# 11 \mathrm{~A}) & +7.2^{\mathrm{a}} \\ 9-3,14-16(\# 3) & +6.5 \\ 13-1,70-72(\# 6) & +9.0^{\mathrm{a}} \\ 14-1,33-35(\# 1) & +7.5 \\ 21-1,27-30(\# 1 \mathrm{~B}) & +8.5^{\mathrm{b}} \\ 27-2,56-58(\# 6) & +6.9 \\ 35-2,105-108(\# 1 \mathrm{~N}) & +9.9^{\mathrm{a}}, \mathrm{b} \\ 46-3,36-38(\# 3 \mathrm{~A}) & +7.7 \\ 47-2,67-70(\# \mathrm{P} 5) & +6.8\end{array}$

Site 334

$\begin{array}{ll}24-3,136-140(\# 12) & +4.7 \\ 24-3,136-140(\# 12) & +5.4\end{array}$

Site 335

$\begin{array}{ll}7-2,95-97 ?(\# 7 \mathrm{~B}) & +9.1^{\mathrm{a}} \\ 8-3,61-63(\# 5 \mathrm{~B}) & +8.9 \\ 8-3,61-63(\# 5 \mathrm{~B}) & +9.3 \\ 10-6,28-30(\# 2) & +8.9^{\mathrm{a}}\end{array}$

${ }^{\mathrm{a}}$ Calcite-bearing samples.

b“Low $\mathrm{Zr}$ " geochemical type.

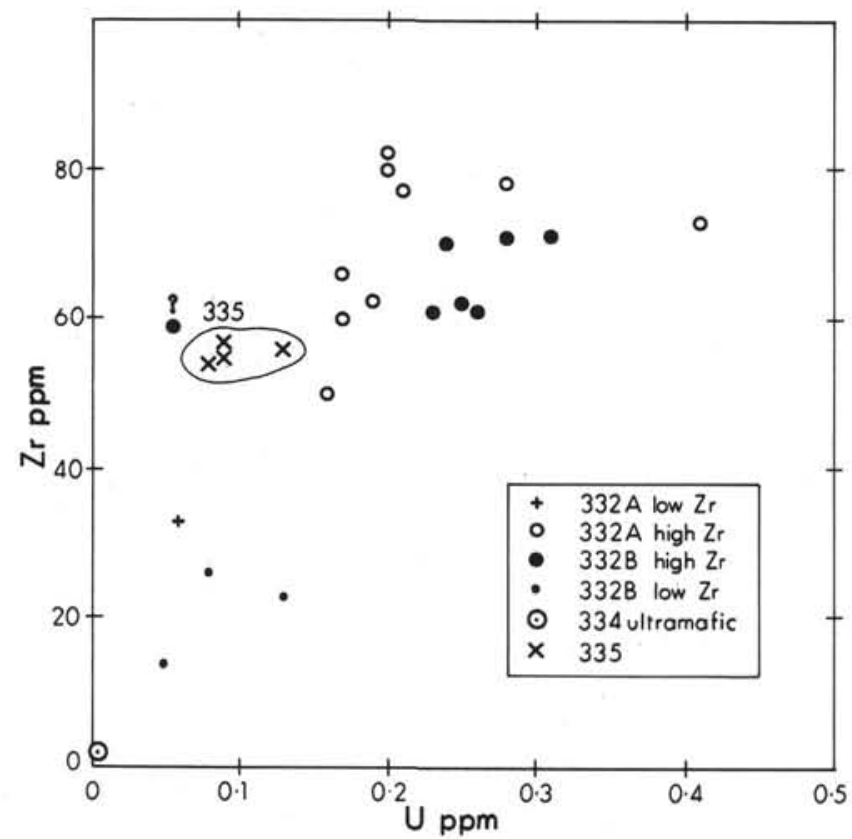

Figure 3. $U$ and $\mathrm{Zr}$ in Holes 332A, 332B, and Sites 334, 335 , showing systematic variation of $U$ with other geochemical parameters exemplified by $\mathrm{Zr}$.
TABLE 3

$\mathrm{U}$ and $\mathrm{Th}$ from Leg 37

\begin{tabular}{lcc}
\hline \multicolumn{1}{c}{$\begin{array}{c}\text { Sample } \\
\text { (Interval in cm) }\end{array}$} & $\mathrm{U}(\mathrm{ppm})$ & $\mathrm{Th}(\mathrm{ppm})$ \\
\hline Hole 332A & & \\
$7-2,15-17(\# 9)$ & $0.406 \pm 0.011$ & $0.6 \pm 0.4$ \\
$8-1,98-100(\# 11)$ & $0.205 \pm 0.008$ & $0.4 \pm 0.3$ \\
$12-1,123(\# 12 \mathrm{D})$ & $0.158 \pm 0.007$ & $0.6 \pm 0.3$ \\
$21-1,57-59(\# 4)$ & $0.166 \pm 0.011$ & $0.9 \pm 0.5$ \\
$26-1,43-45(\# 2)$ & $0.202 \pm 0.008$ & $0.8 \pm 0.3$ \\
$28-1,34-36(\# 4)$ & $0.285 \pm 0.009$ & $0.6 \pm 0.3$ \\
$28-2,57-59(\# 2)$ & $0.212 \pm 0.008$ & $0.7 \pm 0.3$ \\
$29-1,37-39(\# 5)$ & $0.169 \pm 0.007$ & $0.6 \pm 0.3$ \\
$32-1,106-108(\# 14 \mathrm{~B})$ & $0.185 \pm 0.008$ & $1.0 \pm 0.3$ \\
$40-3,37-39(\# 4 \mathrm{~B})$ & $0.064 \pm 0.005$ & bdl
\end{tabular}

Hole 332B

2-5, 103-106 (\#10)

$6-1, \sim 100(\# 11 \mathrm{~A})$

9-3, 14-16 (\#3)

$13-1,70-72(\# 6)$

14-1, 33-35 (\#1)

21-1, 27-30 (\#1B)

27-2, 56-58 (\#6)

35-2, 105-108 (\#1N)

46-3, 36-38 (\#3A)

47-2, 67-70 (\#P5)

$0.048 \pm 0.004 \quad$ bdl

$0.276 \pm 0.010 \quad 0.4 \pm 0.3$

$0.256 \pm 0.009 \quad 0.8 \pm 0.4$

$0.228 \pm 0.009 \quad 0.5 \pm 0.4$

$0.055 \pm 0.005 \quad 1.1 \pm 0.3$

$0.082 \pm 0.005$ bdl

$0.252 \pm 0.009 \quad 0.4 \pm 0.3$

$0.126 \pm 0.006 \quad$ bdl

$0.243 \pm 0.009 \quad$ bdl

$0.307 \pm 0.010 \quad$ bdl

Site 334

24-3, 136-140 (\#12) $0.038 \pm 0.004 \quad$ bdl

Site 335

7-2, 95-97 (\#7B)

8-3, 1-61-63 (\#5B)

8-3, 61-63 (\#5B)

10-6, 28-30 (\#2)

$0.094 \pm 0.006$

$0.130 \pm 0.009$

$0.089 \pm 0.006$

$0.075 \pm 0.006$

$0.5 \pm 0.3$

bdl

bdl

$0.7 \pm 0.3$

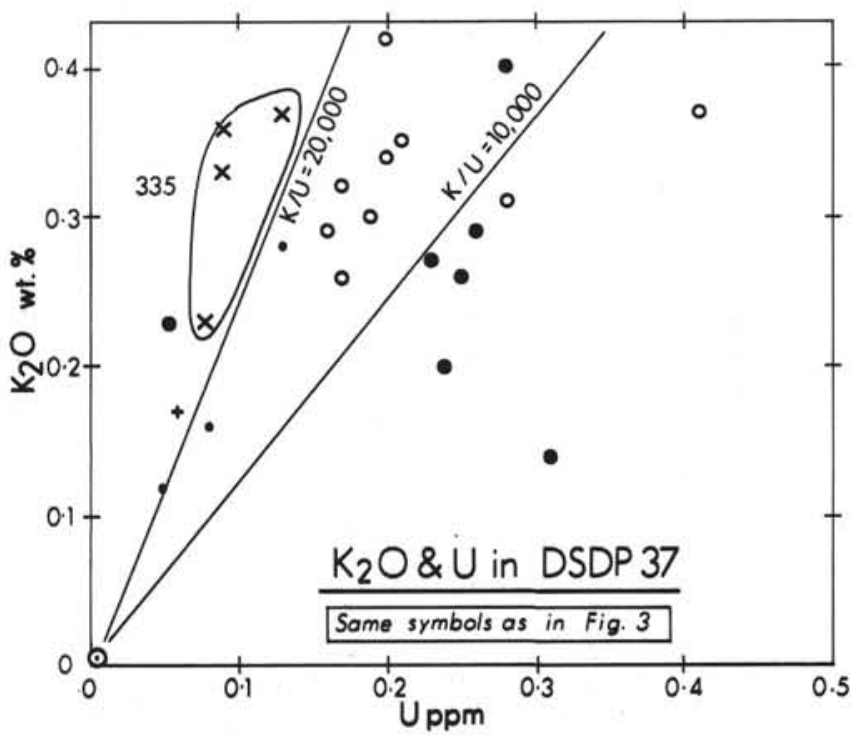

Figure 4. $\mathrm{K}_{2} \mathrm{O}$ and $\mathrm{U}$ in Holes $332 \mathrm{~A}, 332 \mathrm{~B}$, and Sites 334, 335. 